\title{
BIOLOGICAL AND PHARMACOLOGICAL PROPERTIES OF THIAMINE MONOPHOSPHATE DISULFIDE ${ }^{1}$
}

\author{
TAKASHI NOSE, KOZO YASUDA, MOTOTAKA NAKAMA, \\ SHIRO ADACHI, YOSHIO KOWA, SHIGEKI YAMADA, \\ SETSUKO ISHIKAWA AND ICHIRO CHIBATA ${ }^{2}$ \\ Osaka Research Laboratory, Tanabe Seiyaku Co., Ltd., \\ Higashiyodogawa-ku, Osaka
}

(Received October 26, 1965)

The purpose of the present paper is to describe the biological and phamacological characters of thiamine monophosphate disulfide.

\section{EXPERIMENTAL AND RESULTS}

\section{Biological Effect to Rats}

Methods - Healthy young male Wistar-King strain rats weighing about $50 \mathrm{~g}$ were used throughout the experiment. One group was composed of 5 rats and each was kept separately in an isolated cage at $25 \pm 2^{\circ}$ and $55-60 \%$ humidity. The thiamine-deficient diet according to Shimazono (1) was given ad libitum to animals with fresh water. In the main group, 10 and $30 \mu \mathrm{g}$ of thiamine- $\mathrm{HCl}$ and the equivalent amounts of TMPDS dissolved in saline were injected subcutaneously at the intervals of three days from the 20th day. In the control group, only saline was given. The effect of the compound was judged from the average gain in the body weight of each group.

Results-Deficiency symptoms such as cessation of growth, anorexia, slowness of movement, advanced loss of hair and yawning appeared 2 weeks after the start of the experiment, followed by gradual loss of body weight. All the animals in the control group died in 40-45 days (Fig. 1). On the other hand, the group receiving TMPDS or thiamine- $\mathrm{HCl}$ did not show any deficiency symptoms.

2. Absorption after Intravenous Injection

Thiamine and Thiamine Diphosphate Levels in the Blood of Dogs Methods: Dogs of both sexes were used after starvation for 24 hours. TMPDS or thiamine- $\mathrm{HCl}$ corresponding to $2.5 \mathrm{mg}$ thiamine per $\mathrm{kg}$ was given intravenously. Before and $0.5,1,2,4$ and 6 hours after injection, the blood was withdrawn from the brachial vein. Thiamine was determined fluorometrically according to Fujiwara (2) and thiamine diphosphate manometrically according to Uehara (3).

Results: TMPDS showed higher levels of total thiamine and thiamine diphosphate than thiamine- $\mathrm{HCl}$ (Figs. 2 and 3).

\footnotetext{
${ }^{1}$ Studies on Thiamine Monophosphate Disulfide. III. Following abbreviation is used: TMPDS, thiamine monophosphate disulfide.

2 能勢尚志, 安田晃三, 中間元隆, 足立史郎, 甲和良夫, 山田茂樹, 石川節子, 千畑一郎。
} 


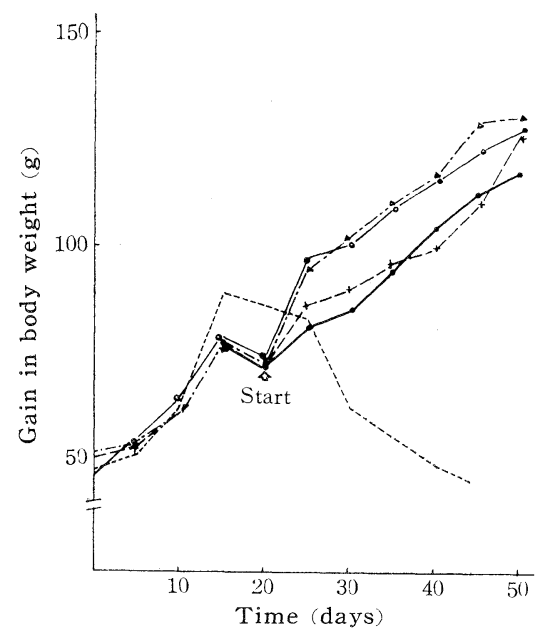

FIG. 1 Curative Test of Thiamine Deficiency in Rats (means of 5 to 10 animals)

- TMPDS eqivalent to $10 \mu \mathrm{g} / \mathrm{kg}$ of thiamine-HCl; $\bigcirc$, TMPDS eqivalent to $30 \mu \mathrm{g} / \mathrm{kg}$ of thiamine- $\mathrm{HCl} ; \times$, thiamine- $\mathrm{HCl}, 10 \mu \mathrm{g} / \mathrm{kg}$; $\Delta$, thiamine- $\mathrm{HCl}, 30 \mu \mathrm{g} / \mathrm{kg}$.

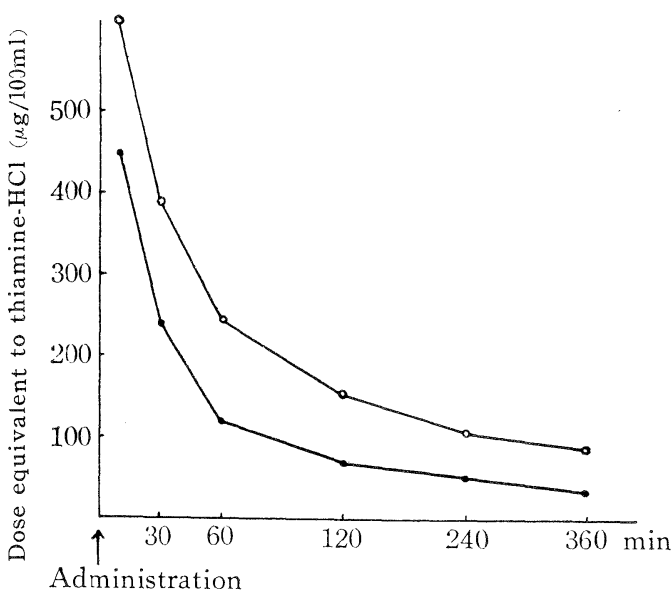

FIG. 2 Total Thiamine Levels in Blood after Intravenous Injection of the Dose Equivalent to $2.5 \mathrm{mg}$ Thiamine- $\mathrm{HCl}$ in Dogs (averages of 4 animals)

$\bigcirc$, TMPDS; $\bullet$, thiamine- $\mathrm{HCl}$.

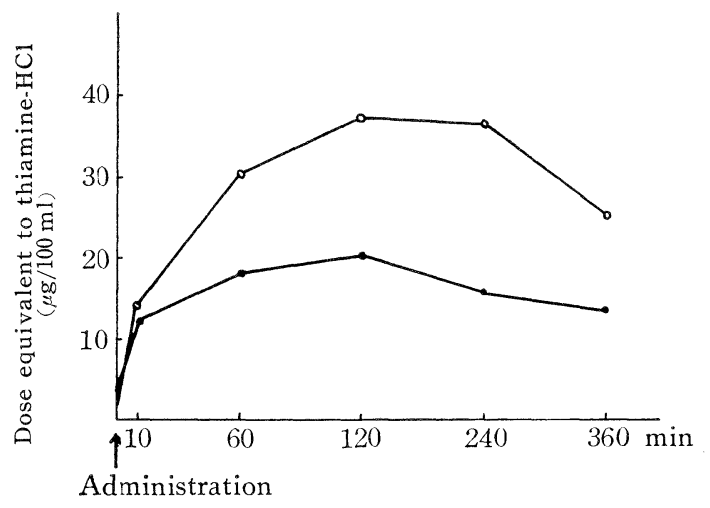

FIG. 3 Levels of Thiamine Diphosphate in Blood after Intravenous Injection of the Dose Equivalent to $2.5 \mathrm{mg}$ Thiamine- $\mathrm{HCl}$ (averages of 4 animals)

○, TMPDS; $\bullet$, thiamine-HCl.

Urinary Excretion in Dogs-Methods: The dogs were treated as described above. After intravenous injection of TMPDS or thimine- $\mathrm{HCl}$ corresponding to $2.5 \mathrm{mg}$ thiamine per $\mathrm{kg}$, the urinary excretion of thiamine after various intervals was determined as follows. The animals were narcotized by an intraperitoneal injection of $40 \mathrm{mg}$ per $\mathrm{kg}$ of pentobarbital sodium. The hypogastrium was opened, a vinyl tube was inserted into the ureter and the abdomen was closed. The urine was collected in a test tube and the thiamine content was determined after 0.5, 1,2 and 3 hours respectively. 
Results: As shown in Fig. 4, in the case of TMPDS, urinary excretion was somewhat retarded. Taking the findings of blood and urine into consideration, TMPDS is considered to be retained more in the body than thiamine-HCl.

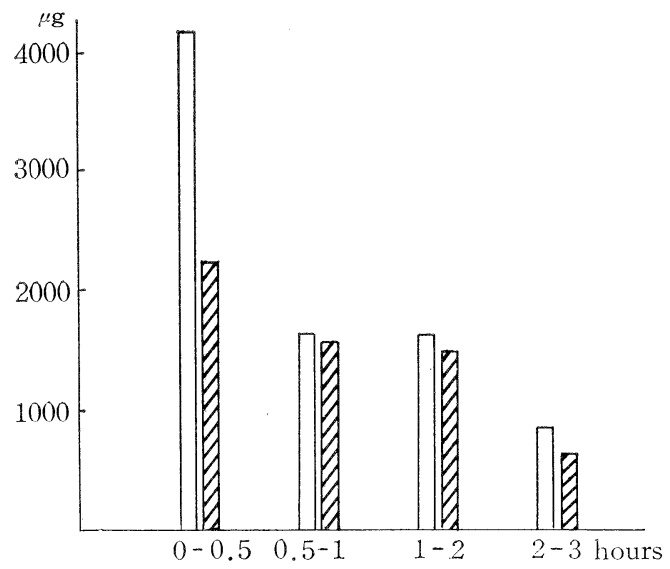

FIG. 4 Urinary Thiamine after Intravenous Injection of the Dose Equivalent to $2.5 \mathrm{mg}$ Thiamine-HCl in Dogs (averages of 4 animals)

限, TMPDS; $\square$, thiamine-HCl.

\section{Analgesic Action in Mice}

Methods - Analgesic effect was investigated according to Takagi (4), using normal male dd strain mice weighing $14 \pm 1 \mathrm{~g}$. In advance the mice were selected which showed a stimulation reflex for pain within 2 seconds after the tail was squeezed by an artery forceps (at $250 \mathrm{~g}$ pressure). Morphine, $1 \mathrm{mg} / \mathrm{kg}$, a dose below the analgesic threshold, was subcutaneously injected. At the same time, TMPDS was injected intraperitoneally. After a certain time period, the stimulus was given as described above. The tails of the mice were again squeezed with an artery forceps and the animals which did not consisted respond to the pain within 4 seconds were regarded as effective. One group of ten animals and $\mathrm{ED}_{50}$ was determined according to Litchfield and Wilcoxon (5).

Results - Table 1 shows that the analgesic effect of TMPDS was similar to the peripheral analgesic action of aminopyrine. $\mathrm{ED}_{50}$ of thiamine- $\mathrm{HCl}$ could not be determined, since excitatory symptoms appeared with the rise of the dose.

TABLE 1

Analgesic Effect of Mice

\begin{tabular}{lcc}
\hline Drug & \multicolumn{1}{c}{ ED $0, \mathrm{mg} / \mathrm{kg}, \mathrm{i} . \mathrm{p} .(95 \%$ C. L.) } \\
\hline TMPDS & 85.6 & 123.0 \\
& $(50.6-155.6)$ & $(81.5-186.1)$ \\
Aminopyrine & 50.0 & 60.1 \\
Thiamine-HCl & $(37.1-67.5)$ & $(40.1-93.0)$ \\
\hline
\end{tabular}




\section{Fatigue Preventive Effect in the Swimming Test of Mice}

Methods-Healthy na-II strain mice weighing $17 \pm 1 \mathrm{~g}$ were used. They were intraperitoneally injected with the sample $(0.1-0.3$ mmole per $\mathrm{kg})$. After 15 minutes, a burden of 3 per cent of the body weight was attached to the proximal part of the tail. One per cent soapless soap solution was applied to the whole body for permeation of water. They were then compelled to swim in a $23^{\circ}$ water-bath until they were too tired to continue swimming, keeping the head over the surface of water.

Results Fig. 5 shows that the swimming time in the TMPDS group was significantly longer than in the thiamine group, the prolongation time being larger with the rise of the dose.

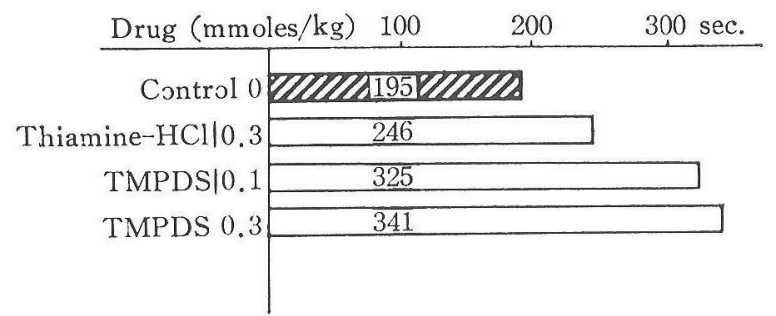

FIG. 5 Fatigue Prevention of TMPDS and Thiamine-HCl in Mice (averages of 20 animals)

\section{Effect on Blood Pressure and Respiration}

Methods The male rabbit, weighing about $2.5 \mathrm{~kg}$, was fixed in a supine position after urethane narcosis, and the neck was incised. Marey's tambour was inserted into the trachea to measure the respiratory function. A mercury manometer was inserted in the carotid artery to determine the blood pressure. Both values were recorded on a kymograph. TMPDS was dissolved in 1.5\% $\mathrm{NaHCO}_{3}$ solution and thiamine- $\mathrm{HCl}$ in saline. Each solution was injected through the auricular vein in the dose of $0.5 \mathrm{ml}$ per $\mathrm{kg}$ of body weight.

Results-Fig. 6 shows that an intravenous injection of TMPDS in a dose

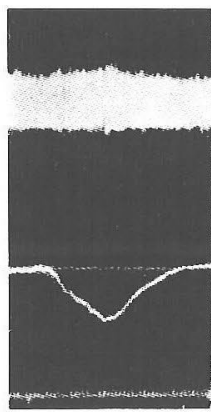

A
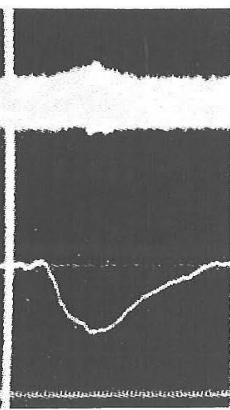

$\mathrm{B}$
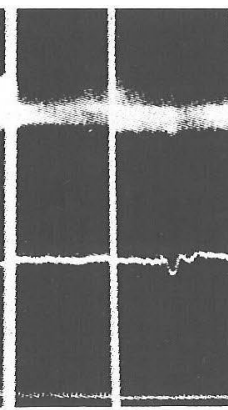

$\mathrm{C}$

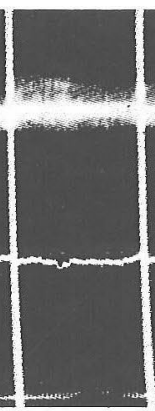

$\mathrm{E}$

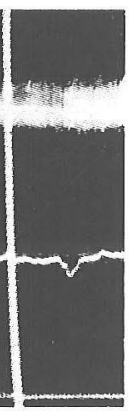

$\mathrm{F}$

FIG. 6 Effects on Blood Pressure and Respiration in Rabbit

A, thiamine- $\mathrm{HCl}, 10 \mathrm{mg} / \mathrm{kg}$; B, thiamine- $\mathrm{HCl}, 20 \mathrm{mg} / \mathrm{kg}$; C, $1.5 \% \mathrm{NaHCO}_{3}$;

D, TMPDS, $10 \mathrm{mg} / \mathrm{kg}$; E, TMPDS, $20 \mathrm{mg} / \mathrm{kg}$; F, TMPDS, $50 \mathrm{mg} / \mathrm{kg}$. 
of $10 \mathrm{mg}$ per $\mathrm{kg}$ resulted in a temporary fall of the blood pressure which returned to the normal level in a short time. In general, the fall of the blood pressure after TMPDS injection was not remarkable, and in some cases the blood pressure did not show any change after injection of $50 \mathrm{mg}$ per $\mathrm{kg}$. On the other hand, an injection of thiamine- $\mathrm{HCl}, 10 \mathrm{mg} / \mathrm{kg}$ resulted in the continuous fall of the blood pressure. Both of them exerted little effect on respiration.

6. Effect on the Auricular Blood Vessel of Rabbits

Methods-After the ear of a rabbit was sharply cut off at the proximal part, they were transfused with a $37^{\circ}$ Tyrode solution according to Krawkow and Pissemski. The dilation or constriction of the vessel in the ear was recorded on a soot paper through a tambour. The flow rate was adjusted to 36 drops per minute. TMPDS was dissolved in $1.5 \% \mathrm{NaHCO}_{3}$ solution and $0.5 \mathrm{ml}$ each of various concentrations was injected in an interval of 30 seconds through the rubber tube at the proximal part of the cannula inserted into the central artery.

Results - TMPDS or thiamine- $\mathrm{HCl}$ solution in the dose of $2.5-10 \mathrm{mg}$ per $\mathrm{ml}$ did not show any definite change (Fig. 7).

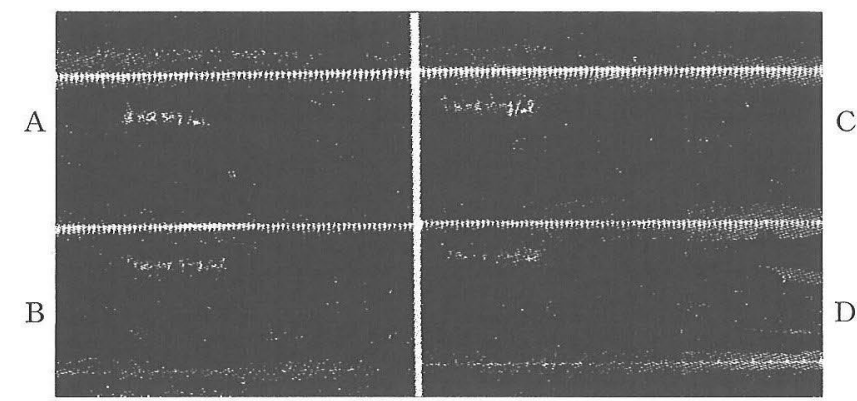

Fig. 7 Effect on Auricular B!ood Vessel in Rabbit

A, thiamine- $\mathrm{HCl}, 5 \mathrm{mg} / \mathrm{ml}$; B, TMPDS, $5 \mathrm{mg} / \mathrm{ml}$; C, thiamine- $\mathrm{HCl}$, $10 \mathrm{mg} / \mathrm{ml}$; D, TMPDS, $10 \mathrm{mg} / \mathrm{ml}$.

\section{Effect on the Isolated Toad Heart}

Methods - A male toad, weighing 200-300 g, was employed. The movement of an isolated heart was recorded continuously, transfusing with Ringer's solution by means of Yagi's transfusion apparatus. The test solution was adjusted to keep at a constant concentration both in the transfusion apparatus and in Ringer's solution.

Results - As shown in Fig. 8, the amplitude of the pulse decreased when

Thiamine- $\mathrm{HCl}$
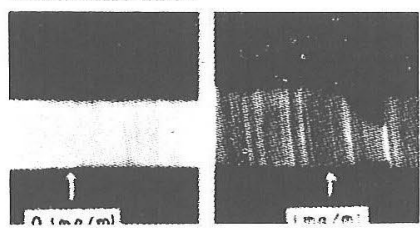

TMPDS

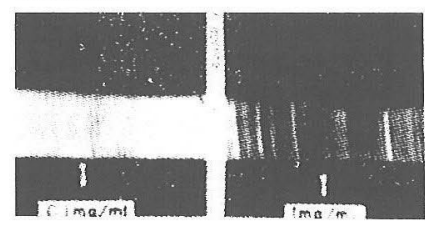

FIG. 8 Effects on Isolated Toad Heart 
the dose was $1 \mathrm{mg}$ per $\mathrm{ml}$ of TMPDS, but did not decrease when the dose was $0.1 \mathrm{mg}$ per $\mathrm{ml}$. When thiamine-HCl was used, the fall of the amplitude was about the same as TMPDS.

\section{Effect on the Isolated Intestine of Rabbit}

Methods - - The isolated intestine was obtained from the ileum of a rabbit killed by bleeding. The movement of the strip of the intestine (about $1-2 \mathrm{~cm}$ in length) was recorded on a kymograph according to Magnus. The strip was suspended in a Tyrode solution kept at $37^{\circ}$ under aeration. The sample solution was adjusted to keep at a constant concentration in the bath.

Results-Fig. 9 shows that both TMPDS and thiamine-HCl did not exert any influence on the movement of the intestine in a dose of $1 \mathrm{mg}$ per $\mathrm{ml}$. In each case, the relaxation and depression of the movement was observed at a concentration of $10 \mathrm{mg}$ per $\mathrm{ml}$ or more, but the effects seemed to depend upon the changes in osmotic pressure and other physical conditions in the water-bath.

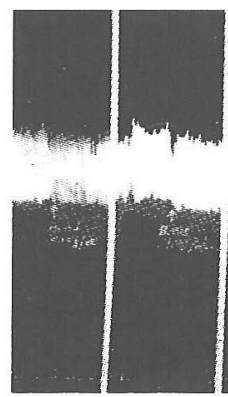

A

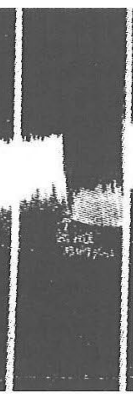

$\mathrm{C}$

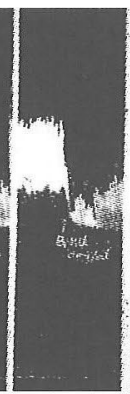

$\mathrm{D}$

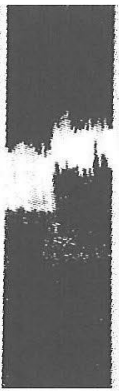

$\mathrm{E}$

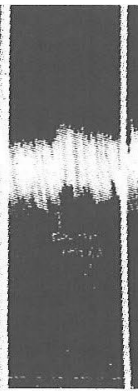

$\mathrm{F}$

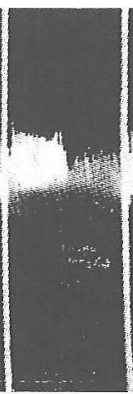

G

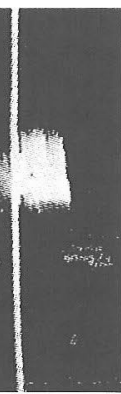

$\mathrm{H}$

FIG. 9 Effects on Extirpated Intestine of Rabbits

A, thiamine- $\mathrm{HCl}, 0.1 \mathrm{mg} / \mathrm{ml}$; $\mathrm{B}$, thiamine $-\mathrm{HCl}, 1 \mathrm{mg} / \mathrm{ml}$; $\mathrm{C}$, thiamine- $\mathrm{HCl}$, $5 \mathrm{mg} / \mathrm{ml}$; D, thiamine- $\mathrm{HCl}, 10 \mathrm{mg} / \mathrm{ml}$; E, $1.5 \% \mathrm{NaHCO}_{3}, 0.5 \mathrm{ml}$; F, TMPDS, $1 \mathrm{mg} / \mathrm{ml}$; G, TMPDS, $10 \mathrm{mg} / \mathrm{ml}$; H, TMPDS, $50 \mathrm{mg} / \mathrm{ml}$.

\section{Effect on the Intestine in situ of Rabbits}

Methods - A laparotomy was performed on a rabbit weighing about $2.5 \mathrm{~kg}$ in the left abdominal part after urethane anesthesia. The small intestine was pulled out and immersedin a $37^{\circ}$ water-bath filled with Tyrode solution. The movement was recorded on a kymograph. TMPDS solution in $1.5 \% \mathrm{NaHCO}_{3}$ or thiamine solution in saline was injected into the auricular vein.

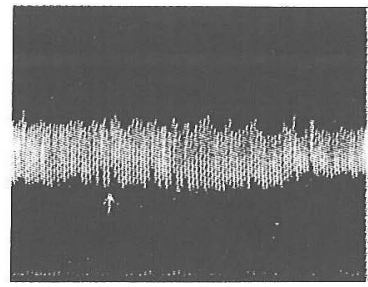

Thiamine-HCl, $20 \mathrm{mg} / \mathrm{kg}$

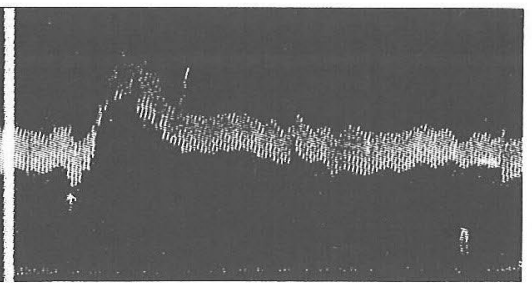

TMPDS, $20 \mathrm{mg} / \mathrm{kg}$

FIG. 10 Effect on Intestine in situ in Rabbit 
Results-As indicated in Fig. 10, a temporary depression of the movement followed by a rise in muscular tension were observed after venous injection of $20 \mathrm{mg} / \mathrm{kg}$ of TMPDS. However, administration of thiamine- $\mathrm{HCl}$ in the same dose did not show any effect on the movement. On the contrary, relaxation was seen in some cases.

\section{Acute Toxity in Mice}

Methods - TMPDS or thiamine- $\mathrm{HCl}$ was given intravenously, intraperitoneally and orally to dd-strain mice, weighing $15 \pm 1 \mathrm{~g}$. They were divided into several groups, each group including 6-10 mice. Intoxication symptoms were observed, and $\mathrm{LD}_{50}$ was calculated from the numbers of death after 24 hours according to Weil (6).

Results - As shown in Table 2, toxicity of TMPDS is exceedingly small. The $\mathrm{LD}_{50}$ values were much less than those of thiamine- $\mathrm{HCl}$. When TMPDS was injected intravenously in a dose of $1-4 \mathrm{~g}$ per $\mathrm{kg}$ in mice, the voluntary movement of the animals was slightly depressed without any further remarkable changes. After an intravenous injection of $4-7 \mathrm{~g}$ per $\mathrm{kg}$, depression of respiratory rate and muscle relaxation appeared and some of them died. After administration of $7 \mathrm{~g}$ per $\mathrm{kg}$ or more, most of the animals died of dyspnoea, muscle relaxation and cyanosis. Five to ten minutes after intraperitoreal injection $5 \mathrm{~g}$ per $\mathrm{kg}$ or more a sudden depression of voluntary movement associated occasionally with seizureattack appeared and some of them died. However, no remarkable change was observed after oral administration of $10 \mathrm{~g}$ per $\mathrm{kg}$.

TABLE 2

Acute Toxicity Test

\begin{tabular}{lcc}
\hline \multirow{2}{*}{ Route } & \multicolumn{2}{c}{ LD $50, \mathrm{mg} / \mathrm{kg}$ (95\% C. L.) } \\
\cline { 2 - 3 } & TDS-MP & Thiamine-HC1 \\
\hline Intravenous & 6.000 & 118 \\
Intraperitoneal & $(5.068-7.103)$ & $(107-130)$ \\
Oral & $\geqq 10.000$ & 317 \\
& $>10.000$ & $(260-382)$ \\
& & $(5.000-10.000)$ \\
\hline
\end{tabular}

\section{Degradation by Thiaminase}

Methods-C Preparation of crude enzyme solution and the condition of enzyme reaction were the same as described in the previous report (7). The substrate solution was diluted with $25 \% \mathrm{KCl}$ in $0.1 \mathrm{~N} \mathrm{HCl}$ to the concentration equivalent to $100 \mu \mathrm{g}$ thiamine- $\mathrm{HCl}$ per $\mathrm{ml}$ and further diluted to $20 \mu \mathrm{g} / \mathrm{ml}$ with water. To $1 \mathrm{ml}$ of the above solution are added $3 \mathrm{ml}$ of intact or heat-inactivated enzyme solution, $1 \mathrm{ml}$ of $1 \mathrm{mg} / \mathrm{ml}$ cysteine hydrochloride and $2 \mathrm{ml}$ of $N \mathrm{NaOH}$. The reaction mixture was kept at $37^{\circ}$ for 15 minutes for reduction. Then, $1 \mathrm{ml}$ of $2 \mathrm{~N} \mathrm{HCl}$ was added to the solution. Further, $1 \mathrm{ml}$ of $6 \%$ Takadiastase was added. After adjustment of $\mathrm{pH}$ to 4.5 , the mixture was kept at $37^{\circ}$ for 1 hour. Thereafter, $5 \mathrm{ml}$ of $25 \% \mathrm{KCl}$ in $0.1 \mathrm{~N} \mathrm{HCl}$ was added and filled with water up to $25 \mathrm{ml}$. A $5-\mathrm{ml}$ aliquot of this solution was used for determination of thiamine by 
the BrCN thiochrome method. The recovery of added TMPDS was found to be $98-102 \%$.

The remaining TMPDS after enzyme reaction was determined after correction with the value with heat-inactivated enzyme.

Degradation by Thiaminase I: The 5- or 10-fold diluted solution of the supernatant fluid of the culture of Bacillus thiaminolyticus was used as the crude enzyme. The degradation of TMPDS by the enzyme was examined under the condition of about 100 and $50 \%$ degradation of thiamine. As shown in Table 3 , TMPDS was proved to be much more resistant to thiaminase I than thiamine$\mathrm{HCl}$.

TABLE 3

Remaining Amount after Degradation by Thiaminase I and II

\begin{tabular}{lcc}
\hline & \multicolumn{2}{c}{ Dilution } \\
\cline { 2 - 3 } & Degradation by thiaminase I $(\%)$ & 10-fold \\
\hline Thiamine-HCl & 3 & 50 \\
TMPDS & 95 & 95 \\
Thiamine-HCl & Degradation by thiaminase II $(\%)$ & 50 \\
TMPDS & 30 & 100 \\
\hline
\end{tabular}

Degradation by Thiaminase II: The supernatant fluid of the culture of Bacillus aneurinolyticus was used as the enzyme solution and the condition was about the same. As shown in Table 3, TMPDS was not degraded at all by thiaminase II. The heat-inactivated solutions of both thiaminase I and II showed no degradation of TMPDS.

\section{SUMMARY}

Thiamine monophosphate disulfide (TMPDS) exhibited the thiamine action in rats nearly equal to that of thiamine-HCl. After intravenous injection of TMPDS in a dog, the levels of total thiamine and thiamine diphosphate in blood were much higher than after administration of thiamine- $\mathrm{HCl}$, retaining the level for a longer period.

On the other hand, TMPDS trended to retard the urinary excretion and it showed benificial effects on analgesic action and prevention of fatigue in swimming of mice.

As for the general pharmacological action of TMPDS, it showed qualitatively similar behaviors against respiro-circulatory systems to those of thiamine- $\mathrm{HCl}$. The former lowered the blood pressure more slowly than the latter in rabbits. Administration of TMPDS, $20 \mathrm{mg}$ per $\mathrm{kg}$, brought about the tension and acceleration of the movement of the intestine in rabbits in situ similarly to thiamine-HCl. In any case, if the pharmacological action of TMPDS is assumed to be a side effect to vitamin action, it is considered to have only a veryr slightly one.

Acute toxicity in mice was much slighter than that of thiamine- $\mathrm{HCl}$ in mice. The compound was found much more resistant to thiaminase I and II than thiamine- $\mathrm{HCl}$. 


\section{REFERENCES}

1. Shimazono, N., Vitamin B Group and Vitamin $B_{1}$ (Japanese), p. 80, Igaku-Shoin, Tokyo, (1950).

2. Yagi, K., Newest Vitamin Assay Methods (Japanese), p. 3, Ishiyaku-Shuppan K. K. Tokyo, (1954).

3. Uehara, K. and Muramatsu, I., Vitamins 11, 583 (1956).

4. Inugai, T., Nakama, M. and Takagi, H., Reported in the 27th Meeting of the Japanese Pharmacological Society, Division of Kinki District (1964).

5. Litchfield, J. T. and Jr., Wilcoxon, F., J. Pharmacol. 96, 99 (1949).

6. Weil, C. S., Biometrics 8, 249 (1952).

7. Chibata, I., Yamada, S., Ito, H., Furutsu, S. and Utsumi, I., Vitamins 25, 83 (1962). 